\title{
Fostering Adaptation by Changing Landowners' Knowledge Framework - Responses to Extension Education in Northwest Washington State, USA
}

\author{
Kevin W. ZOBRIST ${ }^{a^{*}}-$ Lauren A. GRAND $^{\text {a }}-$ Mary A. ROZANCE ${ }^{b}$ \\ ${ }^{a}$ Extension Forestry, Washington State University, Everett, WA, USA \\ ${ }^{\mathrm{b}}$ Institute for Sustainable Solutions, Portland State University, Portland, OR, USA
}

\begin{abstract}
Landscape urbanization and fragmentation, spread of invasive pests, biodiversity loss, social value changes, and loss of manufacturing infrastructure are some of the changing ecological, economic and environmental framework conditions facing small-scale forest owners in northwest Washington State, USA. To successfully adapt to these changes, landowners' knowledge framework must change. Washington State University Extension has been offering comprehensive, multi-week training courses for small-scale forest owners. From 2008 - 2013, participants were surveyed at the conclusion of the training, one year following the training, and again at three years following the training. These follow-up surveys demonstrate a progression from knowledge change to behaviour (management) change and, ultimately, to condition change. Condition changes included increased wildlife diversity, decreased invasive species cover, and increased economic sustainability. The results demonstrate that changing a landowner's knowledge framework through education is a highlyeffective approach for helping them successfully adapt to changing external framework conditions.
\end{abstract}

forestry / Extension / evaluation

Kivonat - Az alkalmazkodóképesség el segítése a földtulajdonosok gondolkodási keretének megváltoztatásával - Észak-nyugat Washington Állam (USA) továbbképzéseinek eredményei. A tájkép beépülése és feldarabolódása, az özönállatok terjedése, a biodiverzitás csökkenése, a társadalmi értékek és a feldolgozási infrastruktúra átalakulása azok az ökológiai, gazdasági és környezeti keret-tényez $\mathrm{k}$, amelyekkel a kisterület erd tulajdonosoknak szembe kell nézniük Washington Állam (USA) északnyugati részében. A változásokhoz történ sikeres alkalmazkodás érdekében a földtulajdonosok gondolkodási kereteinek is változni kell. A Washington Állami Egyetem továbbképzései átfogó, többhetes kurzusokat ajánlanak a kisterület erd tulajdonosok számára. 2008 és 2013 között a résztvev $\mathrm{k}$ felmérésben vettek részt közvetlenül a képzés lezárásakor, majd azt követ en 1 és 3 év múlva. Ezek az után-követ felmérések bemutatják a megszerzett tudás átalakulását magatartássá, majd végs soron a peremfeltételek megváltozásává. Ez utóbbi magában foglalja az állatvilág változatosságának növekedését, az özönfajok csökkenését és a gazdasági fenntarthatóság növekedését. Az eredményeken keresztül látható, hogy a tulajdonosok gondolkodási kereteinek oktatással történ megváltoztatása kiemelked en hatásos módja annak, hogy segítsük ket a változó küls keretfeltételekhez történ alkalmazkodásban.

erd gazdálkodás / továbbképzés / értékelés

\footnotetext{
*Kevin W. Zobrist: kevin.zobrist@wsu.edu; 600 128th St SE Everett, WA, USA 98208.
} 


\section{INTRODUCTION}

Small-scale forest owners in northwest Washington State, USA face a variety of changing ecological, economic, and social framework conditions. Expanding urbanization is resulting in the loss and fragmentation of the forest land base (Bradley et al. 2007). A changing regulatory framework, in response to concerns about water quality and salmon habitat, increases the complexity and decreases the profitability of forest management on small ownerships (Zobrist - Lippke 2003). Changing log markets and manufacturing infrastructure are resulting in changing management trends (e.g. Mason 2003). Other issues such as invasive species and available wildlife habitat are cited by landowners as additional areas of concern (Zobrist - Rozance in press (a)).

Changing landowners' knowledge framework through education can help them adapt to these changing conditions. Landowners identify education and technical assistance as preferred methods for helping them implement good forest management practices (Jones et al. 1995, Kilgore et al. 2007). This study examines whether a forest landowner education program effectively changes landowners' knowledge framework in a way that subsequently leads to behaviour and condition changes (i.e. adaptation to changing framework conditions).

\section{BACKGROUND}

Forest Stewardship Coached Planning is one of the flagship landowner education and outreach programs offered by Washington State University (WSU) Extension. The program is done in partnership with the Washington Department of Natural Resources (DNR), the United States Forest Service (USFS), and other state and local partners. The program is offered several times per year at different locations around the state, reaching thousands of family forest owners since its inception in 1992 (Baumgartner et al. 2007). Coached planning is typically seven to nine weeks in length and includes class sessions one evening per week, a Saturday field day, and a site visit to each participant's property by a state service forester, usually from the DNR.

Coached Planning is a comprehensive education course that covers a broad spectrum of topics including species identification, stand dynamics, soils, forest health, wildlife, invasive species, silviculture, regulations, water quality, forest inventory, wildfire, and special forest products. The course is focused on coaching landowners in the writing of their own forest stewardship plans (also called management plans) that encompass all of these topics and provide a roadmap for successful management and adaptation. The writing of stewardship plans, coupled with site visits from state service foresters, helps participants synthesize class information and apply it to their individual properties. Downing and Finley (2005) found that learning information that applies to an individual's personal situation is important to landowners. In Washington, management plans have additional benefits, as qualifying landowners can use their plans to meet eligibility requirements for cost share assistance, preferential property tax treatment, and forest certification (Zobrist 2011).

Washington's Forest Stewardship Coached Planning program, along with the corresponding technical assistance from DNR foresters, has been supported in part by the USFS Forest Stewardship Program, a nationwide initiative launched in 1991 to promote written stewardship plans for small-scale forest owners. In many states, funding from this program has been used to provide landowners with professionally-prepared plans. A few states, like Washington, offer the coaching option for landowners to self-prepare plans (Esseks - Moulton 2000). 
In the period from 2008 - 2013, 12 coached planning classes were offered in various locations across four northwest Washington counties: King, Snohomish, Skagit, and Island. Two additional classes were offered online in a webinar format. This region, which includes most of the Seattle metropolitan area, has over 50,000 small forest landowners managing over 167,000 hectares of forest (Rogers - Cooke 2009). The total attendance for these classes was 507 people representing 333 families or organizations. Most attendees were family forest owners, but there were several attendees representing municipalities and non-profit organizations related to land stewardship.

\section{METHODS}

Evaluations were done at four different times: midway through the course, at the end of the course, one year after the course, and three years after the course. The evaluations midway through and at the end of the course collected feedback about the first and second halves of the class, respectively. These evaluations were done for each of the 14 classes, though data for one class in 2011 is missing and not included in this study. In addition to gathering feedback to improve future classes, the purpose of these evaluations was to assess short-term impacts of knowledge change due to the course. This was done as a retrospective pre-test (also called a then-test), coupled with a post-test, asking participants to rank their before and after knowledge of different course topic areas using a five-point Likert scale, with one being not knowledgeable and five being very knowledgeable. A two-sample t-test was used to test for significant differences between the results of the retrospective pre-test and the post-test.

A retrospective pre-test was chosen because of an expectation of a strong response-shift bias with a true pre-test. This bias is introduced when participants recalibrate their perception of their knowledge based on what they learned. This can result in an underestimate of gains, and in some cases the post-test scores may even be lower than the pre-test scores, as participants find there is much more they do not know about a topic than they realized before the education event. This phenomenon was observed when evaluating a past program, and program participants have commonly expressed things like "I did not know what I did not know."

The one-year and three-year post-class evaluations were done as mail surveys. One-year evaluations were done for 11 classes from 2008 through 2012. Three-year evaluations were done for five classes from 2008 through 2010. The survey method was roughly based on the Tailored Design Method proposed by Dillman (2007). A pre-notice was sent a few days in advance by email. The survey was then sent by mail along with a cover letter and postagepaid return envelope. A thank you and reminder letter was sent by mail, along with a new copy of the survey and a new postage-paid return envelope, two weeks after the first mailing. A second reminder letter was sent two weeks after the first reminder, also with a new copy of the survey and a new postage-paid return envelope. Thank you and reminder emails were also sent one week after the first survey mailing and one week after the first reminder letter mailing. Only those participants who agreed at the beginning of the course to participate in follow-up surveys and who provided a valid mailing address were surveyed. Only one survey was sent per household.

The focus of the one-year survey was on behaviour change due to taking the course. The survey included questions about whether participants used new knowledge from the course to complete a stewardship plan, implement stewardship practices, and/or share information with others. A chi-squared test was used to compare the behaviour change between those who completed a written stewardship plan and those who did not. The one-year survey also included questions about whether the course increased participants' enjoyment of their forest 
land, their understanding of the ecological importance of their forest land, and their likelihood of utilizing the services of a professional forester if harvesting timber.

The focus of the three-year survey was on condition change. Participants were asked if they had a stewardship plan and, if so, how often they referred to it. Participants were asked if they observed increased wildlife use or decreased invasive species cover after implementing practices using knowledge gained from the course. Participants were asked if they used course knowledge and/or their stewardship plan to sell any timber or non-timber products, enrol in a cost share program, or enrol in a preferential property tax program. Participants were also asked if their comfort and confidence as landowners and their overall quality of life as landowners had improved due to taking the course.

\section{RESULTS}

\subsection{Knowledge self-assessment results}

Table 1 summarizes the mean self-assessment responses for topic knowledge before and after the course. Not every topic was covered in every class, and knowledge of how to write a stewardship plan was not surveyed before 2011, so some $\mathrm{n}$ values are noticeably lower than others. All topics showed a mean knowledge gain of at least 1 point (on a scale of 1 to 5), and all gains were significant at $\alpha=0.01$. How to write a stewardship plan showed the greatest knowledge gain, followed by forest inventory and timber sale management. Native trees, wildlife, and invasive species showed the smallest gains, but these topics also had the highest levels of pre-class knowledge.

Table 1. Mean topic knowledge rating before and after the course, on a scale of 1 (not knowledgeable) to 5 (very knowledgeable)

\begin{tabular}{lccccccccc}
\hline & \multicolumn{7}{c}{ Before the course } & \multicolumn{7}{c}{ After the course } & & & \\
Topic & Mean & SD & $\mathrm{n}$ & Mean & SD & $\mathrm{n}$ & change & $\mathrm{t}$ & $\mathrm{p}$ \\
\hline Native trees & 2.64 & 1.15 & 257 & 3.89 & 0.81 & 255 & 1.25 & 14.23 & $<.001^{*}$ \\
Wildlife & 2.67 & 0.97 & 254 & 4.08 & 0.71 & 252 & 1.41 & 18.68 & $<.001^{*}$ \\
Invasive species & 2.40 & 1.05 & 200 & 3.97 & 0.73 & 201 & 1.57 & 17.38 & $<.001^{*}$ \\
Forest taxes & 1.98 & 1.11 & 170 & 3.56 & 0.93 & 168 & 1.59 & 14.16 & $<.001^{*}$ \\
Stand dynamics & 2.21 & 1.07 & 277 & 3.80 & 0.72 & 272 & 1.59 & 20.32 & $<.001^{*}$ \\
Forest soils & 1.89 & 0.97 & 289 & 3.52 & 0.74 & 283 & 1.63 & 21.49 & $<.001^{*}$ \\
Silviculture & 1.94 & 0.92 & 258 & 3.64 & 0.96 & 253 & 1.70 & 20.47 & $<.001^{*}$ \\
Importance of plans & 2.39 & 1.24 & 269 & 4.13 & 0.80 & 268 & 1.74 & 19.34 & $<.001^{*}$ \\
Regulations & 1.78 & 0.94 & 220 & 3.53 & 0.77 & 220 & 1.75 & 21.31 & $<.001^{*}$ \\
Non-timber products & 1.99 & 0.93 & 247 & 3.75 & 0.77 & 247 & 1.75 & 22.83 & $<.001^{*}$ \\
Forest health & 2.07 & 0.91 & 258 & 3.86 & 0.70 & 255 & 1.79 & 25.01 & $<.001^{*}$ \\
Timber sale & 1.44 & 0.81 & 108 & 3.36 & 0.86 & 107 & 1.93 & 16.89 & $<.001^{*}$ \\
Forest inventory & 1.88 & 0.94 & 120 & 3.82 & 0.74 & 119 & 1.94 & 17.73 & $<.001^{*}$ \\
Plan writing & 1.45 & 0.84 & 131 & 4.08 & 0.74 & 131 & 2.63 & 26.79 & $<.001^{*}$ \\
\hline
\end{tabular}

* Significant at $\alpha=0.01$

\subsection{One-year follow-up results}

The one-year follow-up surveys were sent to 234 households who agreed to participate and provided valid contact information ( $87.3 \%$ of 268 originally participating households). There were 209 responses (89.3\% response rate). Table 2 summarizes participant responses. 
Approximately $65 \%$ completed a written plan, and over $90 \%$ used course knowledge to implement stewardship practices. Practices implemented are summarized in Table 3 and Table 4. Wildlife habitat enhancement, invasive weed control, and fire risk reduction practices were applied to the greatest total area, and trail building was applied to the greatest total distance. Wildlife habitat enhancement, invasive species control, and tree planting were applied by the greatest number of respondents.

Table 2. Summary of participant responses in the one-year follow-up evaluation

\begin{tabular}{lccc}
\hline & No & Yes & \% yes \\
\hline Completed a stewardship plan & 71 & 131 & 64.9 \\
Implemented practices using course knowledge & 20 & 184 & 90.2 \\
Shared course knowledge with others & 8 & 199 & 96.1 \\
Increased enjoyment of property & 21 & 187 & 89.9 \\
Increased understanding of ecological importance of property* & 15 & 124 & 89.2 \\
Increased likelihood of using a professional forester when & 9 & 92 & 91.1 \\
$\quad$ harvesting timber** & & &
\end{tabular}

*Asked of 2009 and later classes

**Asked of 2010 and later classes

Table 3. Stewardship practices applied within one year using course knowledge

\begin{tabular}{lcc}
\hline Practice & $\begin{array}{c}\text { Participants } \\
\text { implementing }\end{array}$ & $\begin{array}{c}\text { Area treated } \\
\text { (ha) }\end{array}$ \\
\hline Regeneration harvest & 26 & 30.6 \\
Commercial thin & 7 & 63.5 \\
Animal damage protection & 44 & 101.1 \\
Pre-Commercial thin & 40 & 138.8 \\
Pruning & 64 & 137.3 \\
Other vegetation control & 87 & 159.8 \\
Tree planting & 92 & 162.8 \\
Fire risk reduction & 71 & 238.1 \\
Invasive weed control & 126 & 288.1 \\
Wildlife habitat enhancement & 100 & 491.2 \\
\hline Total & & 1811.8 \\
\hline
\end{tabular}

Table 4. Kilometres of stewardship practices applied within one year of the course

\begin{tabular}{lcc}
\hline Practice & $\begin{array}{c}\text { Participants } \\
\text { implementing }\end{array}$ & $\begin{array}{c}\text { Distance treated } \\
(\mathrm{km})\end{array}$ \\
\hline Streamside habitat improvement & 31 & 22.8 \\
Road improvement & 30 & 33.1 \\
Trail building & 63 & 84.3 \\
\hline
\end{tabular}

Of those who completed a stewardship plan, 94\% implemented stewardship practices using course knowledge compared to $86 \%$ of those who did not complete a stewardship plan (Table 5). The results of the chi-squared test indicate that this difference is significant at $\alpha=0.10$, but just barely insignificant at $\alpha=0.05\left(\chi^{2}=3.81 ; p=0.051\right)$. 
Table 5. Comparison of practices implemented between those who did and did not complete plans

\begin{tabular}{lcc}
\hline & \multicolumn{2}{c}{ Completed a plan } \\
& Yes & No \\
\hline Implemented practices & $122(94 \%)$ & $59(86 \%)$ \\
Did not implement practices & $8(6 \%)$ & $10(14 \%)$ \\
\hline
\end{tabular}

Approximately $96 \%$ of respondents reported sharing course information with others in the year following the course. The total number of people that respondents reported sharing with was 2,212, which is an average of approximately 11 people per participant who shared. Approximately $90 \%$ of participants reported that the course resulted in a greater enjoyment of their property, a greater understanding of its ecological importance, and a greater likelihood of utilizing a professional forester if harvesting timber.

\subsection{Three-year follow-up results}

For the three-year follow-up surveys, surveys were sent to 123 households who agreed to participate and provided valid contact information $(86.0 \%$ of 143 originally participating households). There were 101 responses (82.1\% response rate). Table 6 summarizes participant responses. The percent of respondents with completed plans increased to $85.9 \%$ at the three-year mark. Those who completed a plan reviewed it an average of 1.4 times per year. Over half of the participants observed increased wildlife use and decreased invasive species cover due to practices implemented using course knowledge. Almost all respondents reported that the course increased their comfort and confidence as a forest owner and decision maker, and that the combination of course impacts increased their overall quality of life.

Table 6. Summary of participant responses in the three-year follow-up evaluation

\begin{tabular}{llcc}
\hline & No & Yes & $\%$ yes \\
\hline Completed a stewardship plan & 14 & 85 & 85.9 \\
Increased wildlife use observed & 37 & 49 & 57.0 \\
Decreased invasive species cover & 30 & 57 & 65.5 \\
Sold products using course knowledge & 69 & 17 & 19.8 \\
Enrolled in a cost share program & 65 & 12 & 15.6 \\
Enrolled in preferential tax program & 34 & 47 & 58.0 \\
Increased comfort/confidence as forest owner & 0 & 95 & 100 \\
Increased quality of life & 3 & 87 & 96.7 \\
\hline
\end{tabular}

Over half of the respondents used their stewardship plan to enrol in a preferential property tax program for forestry. Those who did reduced their property tax liability by an average of $\$ 1,489$ USD per year. Fewer than $20 \%$ of respondents reported using course knowledge to sell timber or non-timber products or enrol in a cost share program. Those who sold products generated a combined total of \$516,243 USD in income. Those who enrolled in a cost share program received a combined total of $\$ 42,710$ USD in cost share funds. When asked to rank their likelihood of converting their property to non-forest use before and after taking the course (highly unlikely, unlikely, neither likely nor unlikely, likely, very likely), $30.8 \%$ reported a lower likelihood, $3.3 \%$ reported an increased likelihood, and $65.9 \%$ reported no change. Of those who reported no change, all were either unlikely or highly unlikely. 


\section{DISCUSSION}

\subsection{Knowledge change}

The results of this study suggest that education through the Forest Stewardship Coached Planning course successfully changes the knowledge framework of small-scale forest owners in northwest Washington State. Knowledge gains were significant across all 14 topics. The extent of these gains should be viewed with some caution. Although a retrospective pre-test can be used to counter response-shift bias, it introduces different biases that can result in overestimating the effect of a program, especially when measuring a socially-desirable outcome like knowledge gain (Hill - Betz 2005). Thus, these results should be viewed with an understanding that they represent participants' subjective views of how they have changed. Future studies may warrant different methods to reduce or better understand potential biases. The results of this study show that the greatest knowledge increase is in how to write a forest stewardship plan, which reflects the overall emphasis of the course. The one-year follow-up results show that participants share their new knowledge with an average of 11 people per person in the first year after taking the course, which represents a multiplying of the knowledge change. Further study to investigate the impact of this indirect influence of the course would be beneficial.

\subsection{Behaviour change}

The one-year evaluation results indicate a progression from knowledge change to behaviour change, with $90.2 \%$ of respondents reporting using knowledge gained from the course to implement stewardship practices on their property. This is higher than the $73 \%$ reported in a 14-year state-wide retrospective study of the program done by Baumgartner et al. (2007). However, that study asked the question differently, asking about practices that the landowner would not have done otherwise. This study asked in more general terms about practices implemented using course knowledge. There may have been practices that the landowner would still have done if not for the course, but that the practice was done differently through the application of course knowledge. Both cases indicate a behaviour change for the vast majority of participants.

This study found that plan completion rates, especially after three years, are higher than the $61 \%$ reported by Baumgartner et al. (2007). It is unknown why the 2008-2012 results are higher than those from 1992-2005. This could reflect improvements to the course, changes in instructors, or region-specific differences between northwest Washington and the rest of the state. Respondents in this study on average reviewed their plans at least once per year. This is similar to a study by Elwood et al. (2003) in the neighbouring state of Oregon that found that all participants used their plans at least annually. In contrast, the results of this study are quite different than a study in West Virginia that found that less than $20 \%$ of participants in a forest stewardship program referred to their plans regularly (Jennings - McGill 2005). The reason for this stark difference is unknown. In West Virginia, stewardship plans are written for landowners by professionals, whereas in this program the landowners write the plans themselves. This could indicate that self-prepared plans get greater use, or that management plans done in conjunction with education get more use. This is an area for future study.

The groups of respondents who did and did not complete a stewardship plan both had high rates of implantation of stewardship practices after one year (94\% and 86\%, respectively). The difference in practice implementation rate between the two groups is significant at $\alpha=0.10$, but insignificant (albeit barely) at $\alpha=0.05$. That both groups have implementation rates greater than $85 \%$ is perhaps more notable than any difference between them, though, especially since the finding of a higher rate of implementation for those who 
completed plans does not establish a cause and effect relationship. These results suggests that the education and assistance aspects of the Coached Planning program drive behaviour change more than writing a stewardship plan. This calls into question whether the production of management plans is the best policy focus when it comes to landowner outreach and assistance, especially when plans are done by professionals and not coupled with landowner education. Further study is needed to understand the most effective drivers of change.

\subsection{Condition change}

The three-year evaluation results suggest a progression from knowledge and behaviour change to condition change. Over half of the respondents reported increased wildlife use and decreased invasive species cover on their property after implementing practices using knowledge gained from the course. The wildlife observations should be treated with some caution, as participants may simply be more aware or observant of wildlife use based on what they learned in the class. The decrease in invasive species cover, however, is likely to stem from practices implemented to control these species. This represents an important adaptation to one of the changing ecological framework conditions (the spread of invasive species) facing small-scale forest owners.

Unlike the one-year follow-up survey, the three-year survey did not ask respondents if they implemented specific practices like wildlife habitat improvement or invasive species control. Thus, these results do not connect specific practices with outcomes. As such, these results are not indicative of the effectiveness of specific practices, but rather are indicative of the impact of the program as a whole relative to these specific areas of interest.

Another adaptation seen in the three-year results is economic adaptation. Over half the participants used course knowledge to get their property enrolled in a preferential property tax program for forestry, saving $\$ 1,489$ USD per year on average. Forest land that is taxed based on highest and best use rather than forestry use can be a significant impediment to economic sustainability (D'Amato et al. 2010). Forest landowners have cited property tax burdens as a key factor influencing them to parcel their property or sell it (Butler et al. 2010, Stone Tyrrell 2012). Studies in the U.S. have found that many landowners are not aware of preferential property tax programs for forestry (Rathke - Baughman 1996, Williams et al. 2004, Fortney et al. 2011, Van Fleet et al. 2012). Education about these opportunities, coupled with education about how to write the management plan that is often required for enrolment, can play a significant role in getting landowners enrolled.

This study revealed another economic adaptation, which is using course knowledge to generate income from the sale of timber and non-timber forest products. Fewer participants (approximately 20\%) pursued this compared to those pursuing preferential tax treatment. This is not unexpected, since generating income is not a high ownership value for landowners in northwest Washington (Zobrist - Rozance 2014). Nevertheless, these participants generated over a half a million USD of new income using course knowledge, which is important for economic sustainability and rural economic development.

\subsection{Potential impact on forest conversion rates}

Getting more landowners enrolled in preferential property tax programs may not achieve the policy goals of good land stewardship and reduced forest conversion. While landowners consistently claim that property taxes are one of their top concerns and a driving factor for parcelization and conversion (e.g. Butler et al. 2010, Stone - Tyrrell 2012), empirical results from studies of actual landowner behaviour are mixed. A 1999 study in the state of Tennessee found no difference in intention to change land use within ten years between those who were enrolled in a preferential property tax program and those who were not (Brockett - Gerhard 
1999). While property taxes have been linked empirically to parcelization and conversion, these land use changes are inelastic relative to property taxes, such that lowering property taxes has a disproportionately small impact on slowing parcelization and conversion (Polyakov - Zhang 2007, Poudyal - Hodges 2009). Butler et al. (2010) observed that focus group participants, when unprompted, did not cite property taxes as a key problem nearly as much as they did after they were informed that the study was about tax policies. These studies suggest that, when it comes to conversion and parcelization choices, property taxes are not as great of an influence as landowner testimonials would indicate.

Almost all respondents in this study (89.9\%) reported an increased understanding of the ecological importance of their property due to taking the course. This may be important, as Wadsworth (1999) found that landowners who believe their forest land has an impact on the larger landscape were less associated with an intention to sell or subdivide their property due to financial reasons. That study does not demonstrate cause and effect, though, so increasing ecological understanding does not necessarily lead to a lower likelihood of property sale or conversion. When asked directly to rank their likelihood of converting their land to development before and after the course, 30.8\% reported a lower likelihood while $65.9 \%$ reported no change. Those who reported no change were already unlikely or very unlikely. This brings up another important issue, which is that participants self-selected into the Coached Planning program and thus may represent a biased sample that is more inherently concerned with ecosystem services and land preservation.

Almost all respondents reported greater enjoyment of their property; greater comfort and confidence as forest owners; and greater overall quality of life. These factors may lead to participants maintaining ownership of their property longer or taking additional steps to protect their forest land from development (e.g. conservation easements). Such outcomes are currently unknown, though, and offer opportunities for further study.

\section{CONCLUSIONS}

Overall, this study suggests that education is a successful strategy for changing landowners' knowledge framework in a way that fosters adaptation to a variety of changing conditions. This study finds that the Forest Stewardship Coached Planning program in northwest Washington State, USA, significantly increases landowner knowledge across 14 topic areas. This leads to subsequent behaviour change, which ultimately results in condition changes that represent successful economic and ecological adaptations that improve landowner quality of life. The Forest Stewardship Coached planning program, which combines classroom and field-based education with stewardship plan writing and direct technical assistance, appears to be a highly effective landowner education and outreach model. Education and assistance may be more important factors than management plan writing when it comes to behaviour change, and there are opportunities for further study to explore this as well as gain a better understanding of cause and effect relationships when assessing the impacts of education and outreach programs.

\section{REFERENCES}

Baumgartner, D.M. - Cohn, P.J. - Grotta, A. - Perleberg, A. - HANley, D.P. - Bergstrom, A. - GIBBS, S. (2007): Forest Stewardship Coached Planning in Washington State. Rural Technology Initiative Working Paper 8. University of Washington College of Forest Resources, Seattle, WA, USA. 14 p.

Online: http://www.ruraltech.org/pubs/working/08/working_paper_08.pdf. 
Bradley, G. - Erickson, A. - Robbins, A. - SMith, G. - Malone, L. - Rogers, L. - ConNer, M. (2007): Forest Land Conversion in Washington State. Future of Washington's Forest and Forest Industries Study 4. University of Washington College of Forest Resources, Seattle.

Online: http://www.ruraltech.org/projects/fwaf/final_report/pdfs/05_study4_landconv.pdf.

BRocKeTt, C.D. - GERHARD, L. (1999): NIPF tax incentives: Do they make a difference? J. For. 97 (4): 16-21.

Butler, B.J. - Hewes, J.H. - Catanzaro, P. - Greene, J.L. - Kilgore, M.A. - Kittredge, D.B. - LANGER, J. - MA, Z. - REUBEN, A. - TyrRELL, M. (2010): Effects of federal, state, and local tax policies on family forest owners. Family Forest Research Center Technical Report. 74 p.

D’Amato, A.W. - CAtanZaro, P.F. - DAmery, D.T. - Kittredge, D.B. - Ferrare, K.A. 2010. Are family forest owners facing future in which forest management is not enough? J. For. 108 (1): 32-38.

DiLlman, D.A. (2007): Mail and Internet Surveys - The Tailored Design Method. John Wiley \& Sons, Inc., Hoboken, NJ. 523 p.

DownING, A.K. - FInLEY, J.C. (2005): Private Forest Landowners; What They Want in an Educational Program. Journal of Extension 43 (1).

Online: http://www.joe.org/joe/2005february/rb4.php.

ElWOOD, N.E. - HANSEN, E.N. - OESTER, P. (2003): Management plans and Oregon's NIPF owners: A survey of attitudes and practices. Western Journal of Applied Forestry 18 (2): 127-132.

ESSEKS, J.D. - Moulton, R.J. (2000): Evaluating the Forest Stewardship Program through a National Survey of Participating Forest Land Owners. Center for Governmental Studies, Northern Illinois University.

FORTNEY, J. - ARANO, K.G. - JACOBSON, M. (2011): An evaluation of West Virginia's managed timberland tax incentive program. Forest Policy and Economics 13 (1): 69-78.

HILL, L.G. - BETZ, D.L. (2005): Revisiting the retrospective pretest. American Journal of Evaluation 26 (4): 501-517.

JENNINGS, B.M. - MCGILL, D.W. (2005): Evaluating the effectiveness of the Forest Stewardship Program in West Virginia: Ten-year assessment. Northern Journal of Applied Forestry 22 (4): 236-242.

JonES, S.B. - LUlOFF, A.B. - FINLEY, J.C. (1995): Another Look at NIPF's: Facing our Myths. J. For 93 (9): 41-44.

Kilgore, M.A. - Greene, J.L. - Jacobson, M.G. - Straka, T.J. - Daniels, S.E. (2007): The influence of financial incentive programs in promoting sustainable forestry on the nation's family forests. J. For 105 (4): 184-191.

MASON, L. (2003): After decades of Douglas-fir plantations, is it time for forest landowners to consider planting alder and cedar? Rural Technology Initiative Fact Sheet 22. University of Washington College of Forest Resources, Seattle, WA, USA.

Online: http://www.ruraltech.org/pubs/fact_sheets/fs022/fs_22.pdf

POLYAKOV, M. - Zhang, D. (2008): Property tax policy and land-use change. Land Economics. 84 (3): 396-408.

PoudyAL, N.C. - HodGES, D.G. (2009): Property taxes and rural land values: Their effect on private forest land ownership structure in Texas. Land Use Policy 26: 1100-1105.

RATHKE, D.M. - BAUGHMAN, M.J. (1996): Influencing nonindustrial private forest management through the property tax system. Northern Journal of Applied Forestry 13 (1): 30-36.

Rogers, L.W. - CoOKE, A.G. (2009): The 2007 Washington State Forest Landowners Database. University of Washington College of Forest Resources, Seattle, WA, USA. Online: http:// www.ruraltech.org/projects/wrl/fldb/pdf/The_2007_Washington_State_forest_land_Database.pdf

StONE, R.S. - TYRRELL, M.L. (2012): Motivations for Family forest land Parcelization in the Catskill/Delaware Watersheds of New York. J. For. 110 (5): 267-274.

VAn FleEt, T.E. - KitTredge, D.B. - ButLER, B.J. - CATANZARO, P.F. (2012): Reimagining family forest conservation: Estimating landowner awareness and their preparedness to act with the conservation awareness index. J. For. 110 (4): 207-215.

WADSWORTH, B. (1990): Factors Affecting forest land Conversion and the Feasibility of Cooperative Land Management Efforts at King County's Urban/Rural Interface. M. Sci. Thesis. University of Washington, Seattle. 
Williams, E.D. - GotTFRIED, R.R. - BROCKETT, C.D. - Evans, J.P. (2004): An integrated analysis of the effectiveness of Tennessee's Forest Greenbelt Program. Landscape Urban Plan. 69: 287-297.

ZOBRIST, K. - LIPPKE, B.R. (2003): Case studies examining the economic impacts of new forest practices regulations on NIPF landowners. In Teeter, L. - Cashore, B. - Zhang, D. (eds.): Forest policy for private forestry: Global and regional challenges. CABI Publishing, Wallingford, UK. 203-210.

Zobrist, K.W. (2011): Your Forest Stewardship Plan. Fact Sheet FS060E, Washington State University Extension, Pullman, WA, USA.

Online: https://pubs.wsu.edu/ItemDetail.aspx?ProductID=15445

ZOBRIST, K.W. - ROZANCE, M.A. (2014): Ownership values of small forest landowners in Northwest Washington, USA. In: Proceedings of the IUFRO Joint Conference of 3.08 \& 6.08 "Future Directions of Small-scale and Community-based Forestry." Japan. September 2013. 199-207.

ZoBRIST, K.W. - RoZANCE, M.A. (2015): Forest Landowner Education Interests and Delivery Preferences: A Retrospective Look at Survey Results and Actual Participation. Journal of Extension 53 (5). 
